\title{
Comparison of Proximate Composition and Nutritional Qualities of Fifty-Three Cashew Accessions from Burkina Faso
}

\author{
Judith N. Semporé1, Laurencia T. Songré-Ouattara², Windpouiré Vianney Tarpaga33, \\ Fabrice Bationo ${ }^{2}$, Mamoudou H. Dicko ${ }^{*}$
}

${ }^{1}$ Laboratory of Biochemistry, Biotechnology, Food Technology and Nutrition (LABIOTAN), UFR-SVT, UJKZ, Ouagadougou, Burkina Faso

${ }^{2}$ Food Technology Department, Institute of Research for Applied Sciences and Technologies (IRSAT), CNRST, Ouagadougou, Burkina Faso

${ }^{3}$ National Centre for Specialization in Fruits and Vegetables, Institute of Environment and Agricultural Research (INERA), CNRST, Bobo-Dioulasso, Burkina Faso

Email: *laurenciaouattara@yahoo.fr

How to cite this paper: Semporé, J.N., Songré-Ouattara, L.T., Tarpaga, W.V., Bationo, F. and Dicko, M.H. (2021) Comparison of Proximate Composition and Nutritional Qualities of Fifty-Three Cashew Accessions from Burkina Faso. Food and Nutrition Sciences, 12, 1191-1203. https://doi.org/10.4236/fns.2021.1212087

Received: October 10, 2021

Accepted: December 10, 2021

Published: December 13, 2021

Copyright $\odot 2021$ by author(s) and Scientific Research Publishing Inc. This work is licensed under the Creative Commons Attribution International License (CC BY 4.0).

http://creativecommons.org/licenses/by/4.0/ (c) (i) Open Access

\begin{abstract}
Cashew cultivation is growing in Burkina Faso, but nut production remains low. Identification of high-performance plant material with known varietal characteristics is essential for breeding. This study consisted of physicalchemical and nutritional characterization of almonds from a core selection of 53 cashew accessions from Burkina Faso. Proximate composition included contents in water, lipids, carbohydrates, proteins, ash, cellulose using standard methods. Major constituents were lipids with an average level of $50.71 \%$ $\pm 4.07 \%$, followed by carbohydrates and proteins with average levels of $21.18 \% \pm 3.81 \%$ and $20.62 \% \pm 1.58 \%$, respectively. Average water, ash and cellulose levels were $4.56 \% \pm 0.39 \%, 2.87 \% \pm 0.27 \%$ and $4.61 \% \pm 2.52 \%$, respectively. The analysis of variability within accessions, based on physical and chemical parameters, identified 3 groups that differ in lipids, carbohydrates, proteins, cellulose and energy value. The first group containing 17 accessions of fat-rich cashews, average protein levels and very high energy values is more interesting for tree improvement programs.
\end{abstract}

\section{Keywords}

Anacardium occidental L., Cashew, Composition, Accessions, Burkina Faso

\section{Introduction}

Cashew (Anacardium occidentale L.) is a nut plant native to the tropical region 
of America, particularly in Brazil [1]. Its cultivation has developed spontaneously and naturally in South American countries [2], while in the tropics, especially in many parts of Africa and Asia [3] its presence is attributed to man. The tree is known by different names, caju in Portuguese, cashew in English, cajuil in Spanish or acajou in French [4]. Considered in the past as a forest species to combat erosion and desertification, the cashew tree is now recognized as offering socio-economic opportunities [5] thanks to its false fruit, composed of the apple and the nut.

Cashew cultivation was introduced in the 1960s in Burkina Faso, following the example of Côte d'Ivoire, Mali and Benin, by the services of the Centre Technique Forestier Tropical (CTFT) using seeds from Benin [6]. It has expanded with the increase in orchards, from 1000 ha in 1980 to over 255,000 ha of plantations in 2015 [7]. This increase is the result of the introduction of seedlings and seeds from various origins, as well as the implementation of numerous cashew development programs. In Burkina Faso, the cashew tree is mainly cultivated for its nuts. Worldwide production of raw cashew nuts is estimated to $3,396,680$ tons with a cultivated area of 3,276,756 ha in 2019 [8]. Africa is the first largest producer and exporter of cashew nuts in the world with a production of 2334 405 tons accounting for more than $50 \%$ of production. West Africa production in 2019 was 1,696,417 tons. In Burkina Faso, recent data collection gave a production of 136,558 tons with a cultivated area of 130,011 ha [8]. This important production makes cashew the third agricultural export product of Burkina Faso after cotton and sesame, and amounts to about US\$90 million in business [9].

The socio-economic importance of cashew is linked to the development of its products in agri-food, pharmacology, cosmetics and its beneficial effects on health.

Nutritionally, cashew kernels are of interest for their high energy content, including lipids, proteins, essential fatty acids and some oligo-elements [5] [10].

Industrially, cashew products have many uses in biscuits, pastries, fortified foods, snack products, etc.

Regarding its beneficial effects, several epidemiological and clinical studies have reported nutritional benefits of cashew consumption in the prevention of cardiovascular disease [11], type 2 diabetes [12], gallstones [13], gallbladder removal [14] and colon cancer [15]. Like all oleaginous (oilseeds), almost three quarters of the total calories in cashew nuts are due to fat. The majority $(60 \%)$ of this fat is in the form of monounsaturated fatty acids, a type of fat with beneficial effects on cardiovascular health [11] [16]. In addition, other studies have also shown that walnuts improve mental health [17], increase bone mineral density [18] and decrease the risk of depression [19]. Its long-term consumption was also associated with a reduced risk of weight gain and obesity [20]. This clearly shows the challenge to screen to identify the best cashew accession for commercial breeding purposes.

The cashew industry in Burkina Faso, like many other producing countries, is 
faced with several challenges. These include the heterogeneity of production, low orchard yields, the high rate of atypical plants [21], the lack of knowledge of existing cashew varieties and the potential of their fruits and by-products, the insufficient number of improved seedlings, the low technological level of processing units [9], and the low marketability of end-products. In addition, despite being the third largest export, very little research has been done on cashew nuts in Burkina Faso.

The cashew tree is an allogamous species and therefore does not reproduce identically by sexual means from one generation to the next. Thus, the practice of creating orchards with nuts and seedlings from nurseries is at the root of the low productivity of the national cashew orchard. To remedy this, the national plant breeding institute of (INERA) has been working since 2011 on the selection of mother trees displaying exceptional performance to be used for the creation of the first cashew cultivars in Burkina Faso. These trees were reproduced by grafting and kept as a collection in the INERA/Farako Bâ and Banfora stations for the purpose of safeguarding genetic diversity on the one hand, and selection and varietal improvement on the other. Thus, kernels of agro-morphologically characterized 53 cashew accessions, were physicochemically analysed in order to identify the best accession for commercial breeding.

\section{Materials and Methods}

\subsection{Plant Material}

Plant material consisted of cashew nut samples from 53 agro-morphologically characterized accessions from the Institut de l'Environnement et de la Recherche Agricole (INERA). These nuts were collected in 2020 in nine departments of the two regions of Haut-Bassins and Cascades in Burkina Faso (Table 1).

Accessions from which the nuts are derived are the result of a mass selection process from a population of 820 ecotypes. Prospective surveys in 2011, 2014 and 2015 identified trees with exceptional production from producers and their perceptions. The identified trees in the three areas were 166, 255 and 399 ecotypes, respectively. Each identified tree was monitored for three years in its original environment, following an approach previously described [22]. A screening step based on threshold values of three main performance criteria was adopted. These are kernel content with a threshold value of at least $25 \%$, average raw nut weight with a threshold of $6 \mathrm{~g}$ and total tree production with a threshold of at least $20 \mathrm{~kg}$ for trees younger than 10 years, at least $30 \mathrm{~kg}$ for trees between 10 and 14 years old and $40 \mathrm{~kg}$ for trees at least 15 years old. The collected data underwent a rank test that allowed to screen the collected material and to select the 53 accessions that met the three main criteria.

For each accession, $2 \mathrm{~kg}$ of cashew nuts were sampled from the current crop of the accession and stored in jute bags to be sent to the laboratory of the Department of Food Technology (DTA) of the Institute of Research in Applied Sciences and Technologies (IRSAT). 
Table 1. Origins/area and years of collection of cashew accessions in 2020.

\begin{tabular}{|c|c|c|c|c|}
\hline Regions & Provinces & Departement & $\begin{array}{l}\text { Number } \\
\text { of cashew } \\
\text { accessions }\end{array}$ & $\begin{array}{l}\text { Accession } \\
\text { reference }\end{array}$ \\
\hline \multirow{7}{*}{ Cascades } & \multirow{4}{*}{ Léraba } & Sindou & 18 & $\begin{array}{l}\text { ET01; ET55A } \\
\text { ET17 to ET32 }\end{array}$ \\
\hline & & Ouéléni & 1 & ET42 \\
\hline & & Loumana & 1 & ET43 \\
\hline & & Dakoro & 1 & ET55B \\
\hline & \multirow{3}{*}{ Comoé } & Soubakagniedougou & 8 & $\begin{array}{c}\text { ET02 to ET05; } \\
\text { ET54; ET55C; ET57 }\end{array}$ \\
\hline & & Mangodara & 7 & $\begin{array}{c}\text { ET13; ET52; } \\
\text { ET53; ET60; } \\
\text { ET62; ET63; ET67 }\end{array}$ \\
\hline & & Banfora & 4 & $\begin{array}{l}\text { ET06; ET14; } \\
\text { ET15, ET16 }\end{array}$ \\
\hline \multirow{2}{*}{ Haut-Bassins } & \multirow{2}{*}{ Kénédougou } & Orodara & 7 & ET07 to ET12; ET69 \\
\hline & & Kangala & 6 & ET37; ET45 to ET50 \\
\hline
\end{tabular}

The nuts were crushed into two halves using shears (cashew nut kernel cutter) and the shells were removed to obtain the kernel. These almonds were then separated from their skin, the thin protective membrane that surrounds them. The raw almonds prepared in this way for each sample were weighed and then ground using an electric grinder (KN $\left.195 \mathrm{Knifetec}^{\mathrm{TM}}\right)$. The powder samples obtained were placed in polyethylene jars and stored in the refrigerator at $4^{\circ} \mathrm{C}$ prior to analyses.

\subsection{Determination of Physicochemical and Nutritional Characteristics}

Moisture, fat, protein, ash and carbohydrates were determined according to official AOAC methods.

The moisture content of the samples was determined by differential weighing of a $5 \mathrm{~g}$ sample before and after oven drying at $105^{\circ} \mathrm{C}$ for $12 \mathrm{~h}$ [23]. Ash content was determined by incinerating $5 \mathrm{~g}$ of sample in a muffle furnace (Nabertherm) at $550^{\circ} \mathrm{C}$ for 4 hours, according to the international standard [24]. The fat content of the samples was determined by the Soxhlet extraction method according to the international standard [25] with hexane as solvent. The total protein content was determined by the Kjeldahl method according to the French standard [26]. The total sugar content of the samples was determined by the spectrometric method (Spectrophotometer UNI 002_FR I 200) using orcinol-sulphuric acid reagent (Montreuil and Spik, 1969). The absorbance of the samples was read at $510 \mathrm{~nm}$ with a Fibre residue (FR) was determined by the differential method 
[27] using the formula: FR (\%) $=[100-$ ash (\%) - Proteins (\%) - fats (\%) - sugars (\%)]. The potential energy value (E) was estimated using Atwater coefficients [28] formulas follow: $\mathrm{E}(\mathrm{Kcal} / 100 \mathrm{~g})=$ [carbohydrate content $(\%) \times 4$ $(\mathrm{Kcal})+$ protein content $(\%) \times 4(\mathrm{Kcal})+$ fat content $(\%) \times 9(\mathrm{Kcal})]$.

\subsection{Statistical Analyses}

All physicochemical and nutritional analyses were performed in triplicate. The data were then subjected to an analysis of variance (ANOVA). The Fisher test at the $5 \%$ level was used to compare means. Statistically significant difference was indicated at $\mathrm{p}<0.05$. Hierarchical ascending classification was used to structure the variability on the basis of Euclidean distances and aggregation by Ward's method. A discriminant factor analysis was used to describe the cashew nut accession groups identified. Data processing and all statistical analyses were performed using XLSTAT BASIC + software (Addinsoft, 2016).

\section{Results}

\subsection{Overall Physico-Chemical and Nutritional Composition of Cashew Accessions Kernels}

There were highly significant differences $(\mathrm{P}<0.001)$ within the 53 nut kernel samples for all physico-chemical and nutritional parameters (Table 2). Moisture contents are quite low ranging from $3.71 \%$ to $6.02 \%$, with an average of $4.56 \% \pm$ $0.39 \%$. Ash contents varied from $2.06 \%$ to $3.51 \%$ with an average of $2.87 \% \pm$ $0.27 \%$. Concerning fiber, the diversity is greater within the accessions with contents ranging from $0.66 \%$ to $11.89 \%$, with an average of $4.61 \% \pm 2.52 \%$. Levels of lipids in the nut kernels were ranging from $39.90 \%$ to $57.61 \%$ with an average of $50.71 \% \pm 4.07 \%$. Protein contents of the kernels ranged from $16.76 \%$ to $24.44 \%$ with an average of $20.62 \% \pm 1.58 \%$. The minimum and maximum values for carbohydrate content were $12.20 \%$ and $32.92 \%$ respectively, with an average of $21.18 \% \pm 3.81 \%$. The potential energetic values among accessions range from 557.86 to $673.68 \mathrm{Kcal} / 100 \mathrm{~g}$, with an average of $623.59 \pm 27.00 \mathrm{Kcal} / 100 \mathrm{~g}$.

Table 2. Physico-chemical and nutritional characteristics of cashew kernels from Burkina Faso.

\begin{tabular}{cccccccc}
\hline Characteristics & $\begin{array}{c}\text { Moisture } \\
(\%)\end{array}$ & $\begin{array}{c}\text { Ash } \\
(\%)\end{array}$ & $\begin{array}{c}\text { Cellulose } \\
(\%)\end{array}$ & $\begin{array}{c}\text { Fat } \\
(\%)\end{array}$ & $\begin{array}{c}\text { Protein } \\
(\%)\end{array}$ & $\begin{array}{c}\text { Carbohydrates } \\
(\%)\end{array}$ & $\begin{array}{c}\text { Energy value } \\
(\text { Kcal/100g) }\end{array}$ \\
\hline Number of accessions & 53 & 53 & 53 & 53 & 53 & 53 & 53 \\
Mean \pm SD & $4.56 \pm 0.39$ & $2.87 \pm 0.27$ & $4.61 \pm 2.52$ & $50.71 \pm 4.07$ & $20.62 \pm 1.58$ & $21.18 \pm 3.81$ & $623.59 \pm 27.00$ \\
Minimum value & 3.71 & 2.06 & 0.66 & 39.90 & 16.76 & 12.20 & 557.86 \\
Maximum value & 6.02 & 3.51 & 11.89 & 57.61 & 24.44 & 32.92 & 673.68 \\
Cv (\%) & 8.55 & 9.41 & 54.66 & 8.03 & 7.66 & 17.99 & 4.33 \\
P-value & $<0.0001$ & $<0.0001$ & $<0.0001$ & $<0.0001$ & $<0.0001$ & $<0.0001$ & $<0.0001$ \\
\hline
\end{tabular}

$\mathrm{SD}=$ standard deviation. 


\subsection{Diversity of Physicochemical and Nutritional Characteristics of Cashew Accessions}

Principal component analysis (PCA) was performed on seven variables, including moisture, ash, cellulose, carbohydrates, lipids, protein and energy (Figure 1). The results of the PCA) showed that the first two axes F1 and F2 displayed $61.20 \%$ of the variability within the kernels of cashew accessions. Only two components, i.e. lipids and energy values were strongly and positively correlated to the F1 axis. On the other hand, moisture and carbohydrates of cashew accessions were negatively correlated with the F2 axis, while cellulose was not. The lipid contents and energy values are strongly correlated with each other and inversely correlated with carbohydrates and cellulose. Protein and ash contribute to data of the F2 axis, and are inversely correlated with carbohydrates.

\subsection{Variability within Cashew Accessions Based on Physicochemical and Nutritional Characteristics of the Kernels}

The hierarchical ascending classification (HAC) or dendrogram carried out on the 53 almond samples of cashew accessions also covered seven variables: moisture, ash, fat, protein, cellulose, carbohydrate, energy value (Figure 2). The results

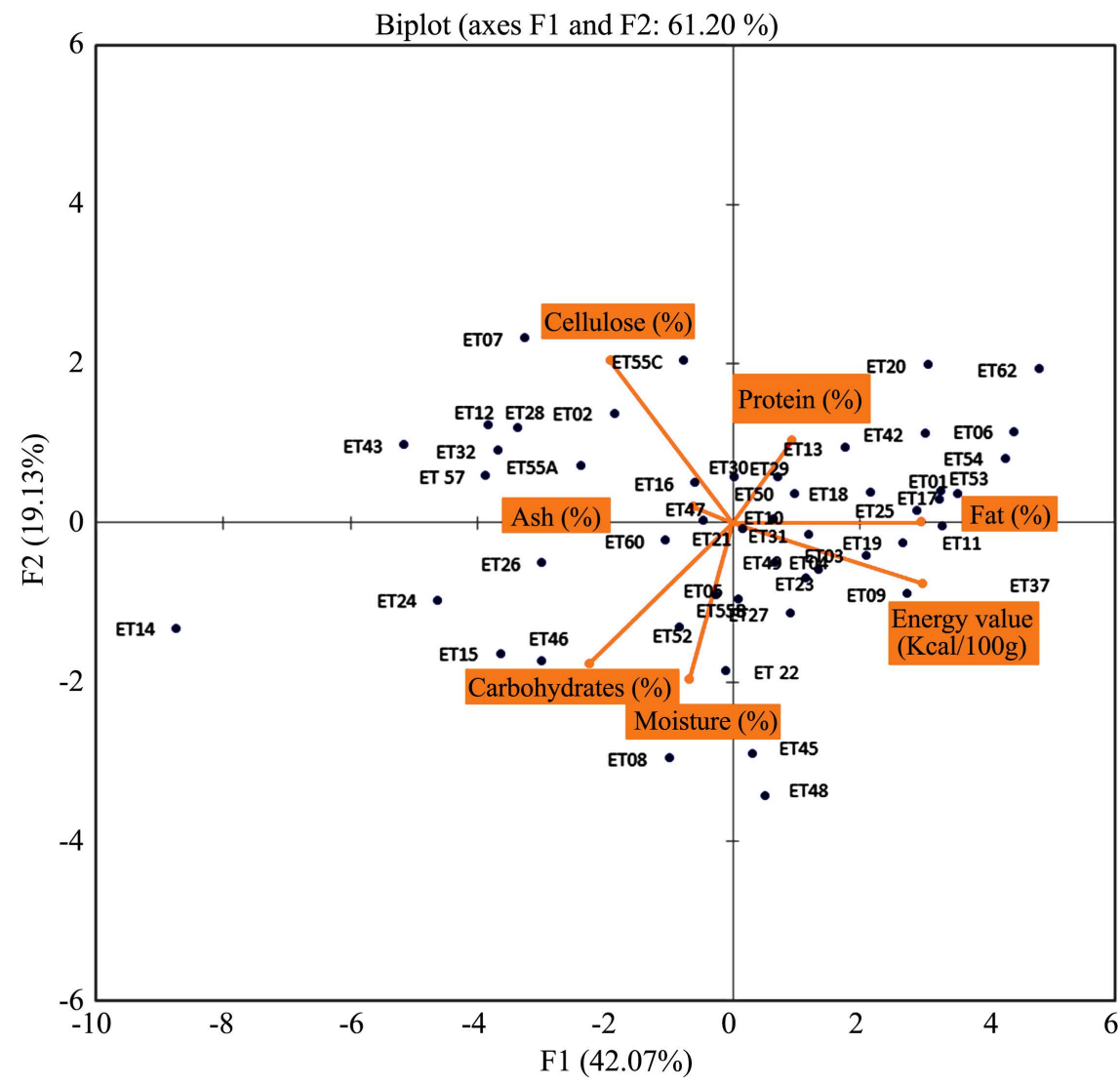

Figure 1. Principal component analysis based on nutritional compounds of cashew accessions. The boxed words represent the parameters of the overall nutritional composition studied. The numbers with the letter ET represent each sample. 


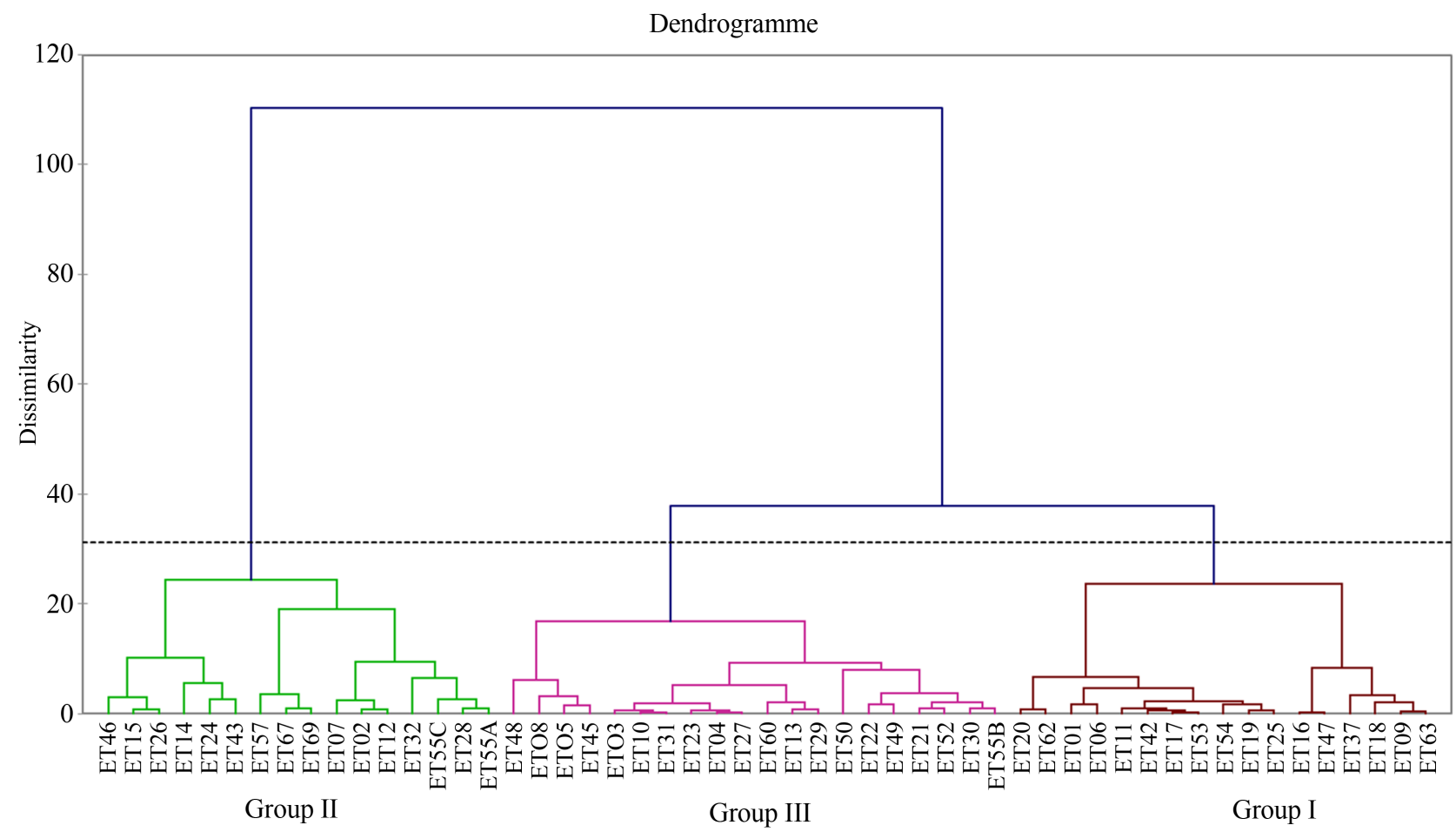

Figure 2. Ascending Hierarchical Classification (AHC) of the 53 accessions according to Ward's aggregation criteria.

of the AHC revealed a structuring of the variability of the accessions into three distinct groups. The variance decomposition shows that the inter-group variability corresponds to $82 \%$ against $18 \%$ for the intra-group variability. Comparison of the group means for the different variables in the discriminant factor analysis (DFA) revealed very highly significant differences for almost all variables with probability values (two-sided P-value) between 0.0001 and 0.008 (Table 3). The graphical representation of the half design of the discriminatory factor analysis (DFA) which explains $100 \%$ of the total variability among groups (Figure 3) together with the group means from the AHC shows a characterization of the groups as follows:

Group I, composed of 17 accessions, i.e. $32.07 \%$ of the total number of accessions, is made up of cashew accessions whose kernels have a high fat $(54.99 \% \pm$ $1.51 \% \mathrm{DM})$ and energy $(648.54 \pm 11.83 \mathrm{Kcal} / 100 \mathrm{~g})$ content, an average protein content $(20.44 \% \pm 1.78 \% \mathrm{DM})$, and low carbohydrate $(17.96 \% \pm 2.39 \% \mathrm{DM})$, ash $(2.76 \% \pm 0.19 \% \mathrm{DM})$ and cellulose $(3.84 \% \pm 1.57 \% \mathrm{DM})$ contents. This group includes accessions from the two regions (Cascades and Haut Bassins) and distributed in eight departments as follows: 7 accessions from Sindou, 3 from Mangodara, 2 from Banfora, 1 from Ouéléni 2, from Orodara, 2 from Kangala. Only the average protein content was comparable to that of the other groups, i.e. $20.44 \% \pm 1.78 \%$ compared to $20.34 \% \pm 1.58 \%$ for group II and $20.98 \% \pm 1.23 \%$ for group III.

Group II consisted of 16 accessions, i.e. $30.18 \%$ of the cashew accessions studied, from the two regions (Cascades and Haut Bassins), including 5 from the 
Table 3. Nutritional performance of cashew nut accession groups.

\begin{tabular}{cccccccc}
\hline Variables & $\begin{array}{c}\text { Moisture } \\
(\%)\end{array}$ & $\begin{array}{c}\text { Ash } \\
(\%)\end{array}$ & $\begin{array}{c}\text { Cellulose } \\
(\%)\end{array}$ & $\begin{array}{c}\text { Fat } \\
(\%)\end{array}$ & $\begin{array}{c}\text { Protein } \\
(\%)\end{array}$ & $\begin{array}{c}\text { Carbohydrates } \\
(\%)\end{array}$ & $\begin{array}{c}\text { Energy value } \\
\text { Kcal/100g }\end{array}$ \\
\hline Groups & & & & & & & \\
G I & $4.38 \pm 0.33$ & $2.76 \pm 0.19$ & $3.84 \pm 1.57$ & $54.99 \pm 1.51$ & $20.44 \pm 1.78$ & $17.96 \pm 2.39$ & $648.54 \pm 11.83$ \\
G II & $4.59 \pm 0.31$ & $2.91 \pm 0.37$ & $7.33 \pm 2.44$ & $45.80 \pm 2.21$ & $20.34 \pm 1.58$ & $23.61 \pm 4.16$ & $588.00 \pm 13.09$ \\
G III & $4.77 \pm 0.43$ & $2.94 \pm 0.21$ & $3.09 \pm 1.13$ & $50.99 \pm 1.68$ & $20.98 \pm 1.23$ & $21.99 \pm 2.21$ & $630.86 \pm 8.15$ \\
P-value* & 0.008 & $\mathrm{~ns}$ & $<0.0001$ & $<0.0001$ & $\mathrm{~ns}$ & $<0.0001$ & $<0.0001$ \\
\hline
\end{tabular}

${ }^{\star}$ Statistics of the Univariate Test of equality of group means. Ns: Not significant.

Observations (axes F1 and F2 : $100.00 \%$ )

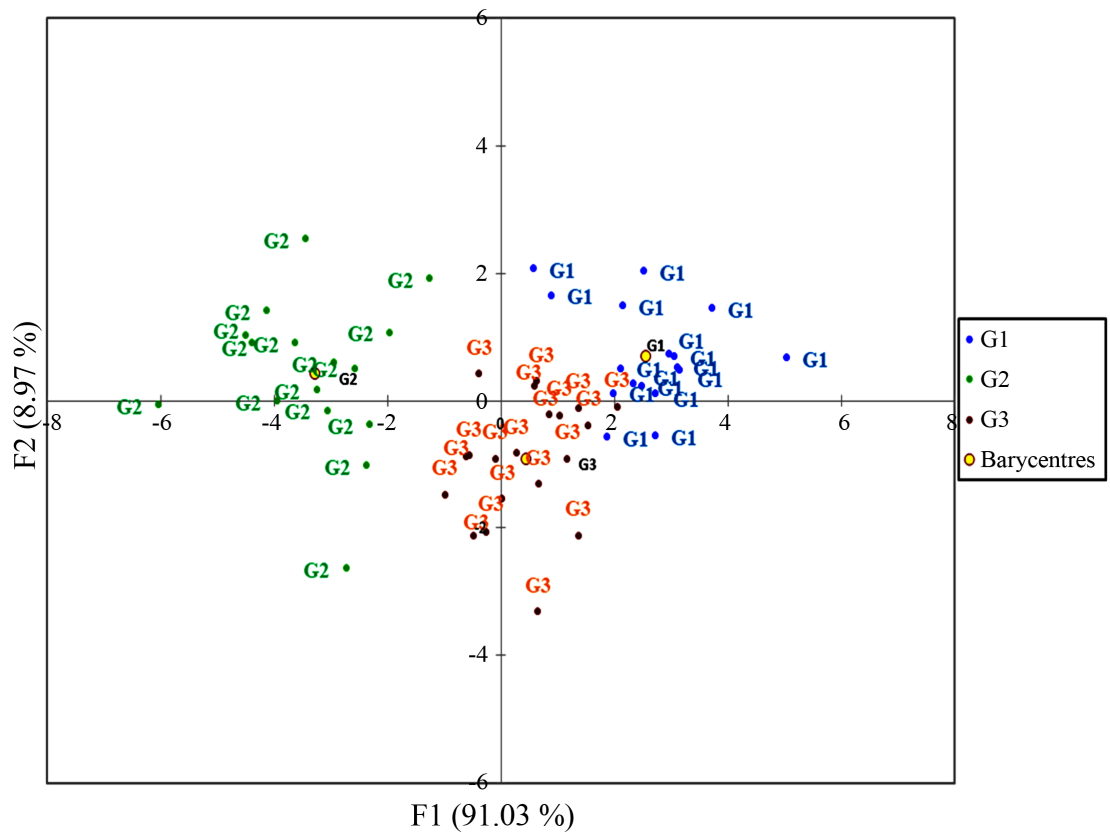

Figure 3. Expression of nutritional diversity of cashew accessions.

department of Sindou, 3 from Soubakagniedougou, 2 from Banfora, 1 from Mangodara, 1 from Loumana, 3 from Orodara and 1 from Kangala. The cashew accessions in this group are opposite to those in group I and were characterised by high carbohydrate $(23.61 \% \pm 4.16 \% \mathrm{DM})$ and cellulose $(7.33 \% \pm 2.44 \% \mathrm{DM})$ contents, and lower lipid $(45.80 \% \pm 2.21 \%$ DM) and energy (588.00 \pm 13.09 $\mathrm{Kcal} / 100 \mathrm{~g}$ ) contents. Their protein contents were comparable to that of the other two groups.

Group III is made up of 20 accessions, i.e. 37.73\%, spread over two regions (Cascades and Haut Bassins), including seven from Sindou, three from Soubakagniedougou, three from Mangodara, one from Dakoro, two from Orodara and four from Kangala. The accessions in this group are characterized by high ash content $(2.94 \% \pm 0.21 \% \mathrm{DM})$, average lipid content $(50.99 \% \pm 1.68 \% \mathrm{DM})$, energy content $(630.86 \% \pm 8.15 \%$ DM), protein content $(20.98 \% \pm 1.23 \% \mathrm{DM})$ 
and carbohydrate content $(21.99 \% \pm 2.21 \% \mathrm{DM})$, but very low cellulose content $(3.09 \% \pm 1.13 \% \mathrm{DM})$, which is lower than that of Group I accessions.

\section{Discussion}

The 53 cashew nuts of accession samples from Burkina were a core collection from a mass selection of cashew trees of good agro-morphological performances. The selection of these accessions was mainly based on agro-morphological criteria such as crude nut yield, average crude nut weight and nut kernel percentage. The improvement process resulted in the selection of 15 cashew accessions as head clones to boost the production of improved seedlings for the industry [22].

Concerning the overall proximate composition, for all the accessions, the average values found in cashew kernels were comparable to the average values reported by [10] for 11 cashew nut samples of different origins, i.e. $3.8 \% \pm 0.8 \%$ for moisture, $48.27 \% \pm 1.55 \%$ for lipids, $21.3 \% \pm 0.8 \%$ for proteins, $20.5 \% \pm$ $1.5 \%$ for carbohydrates, $609 \pm 8.9 \mathrm{kcal} / 100 \mathrm{~g}$ for energy value. Also, they are of the same order of magnitude as data found by on Brazilian cashew nuts [29]. In addition, higher lipid contents were reported on nine cashew nut samples from Indonesia i.e. $66.21 \% \pm 7.87 \%[30]$.

Although lipids represent the major constituent of cashew kernels carbohydrates represent the second major constituent of kernels with values close to proteins. Concerning the moisture content, the average values obtained in this study were lower than those reported on cashew nut flours, i.e. $5.7 \% \pm 0.2 \%$ [31]. The average ash values are also comparable to those reported with cashew nuts from Cote d'Ivoire [32]. However, they are in line with standard specifications which recommend cashew nuts with a moisture content below 5\% [33]. Interestingly, cashews with low moisture content $(<5 \%)$ could have the advantage to be stored for longer periods of time without microbial growth or changes in undesirable biochemical compounds [34]. The comparison with the physicochemical and nutritional characteristics reported for Brazilian peanut seeds shows that the latter are richer in protein $(29.59 \% \pm 0.05 \%)$, lower carbohydrate contents (13.06\%) and comparable lipid contents $(46.35 \% \pm 0.26 \%)$ [10]. Present results also show that the average cellulose content obtained, $4.61 \% \pm 2.52 \%$, is higher than those reported elsewhere [10] [29] [31] with values of $1.2 \% \pm 0.3 \%, 3.92 \% \pm$ $0.05 \%$ and $3.6 \% \pm 0.2 \%$, respectively. The consumption of cashew kernels with high cellulose content could facilitate digestion and prevent constipation which is the cause of some diseases such as hemorrhoids, colon cancer, appendicitis, etc. [32]. Differences related to the origin of the samples, the processes (storage and manipulation), and the methods used for cellulose analysis may explain these differences observed between studies.

In terms of analysis of variability within the cashew accessions nut samples, univariate analyses, including principal component analysis (PCA), hierarchical ascending classification (HAC) and discriminant factor analysis (DFA) allowed the identification of the main discriminant parameters respectively, which are li- 
pids. The 53 cashew accessions were classified into three homogeneous groups consisting of accessions with high nutritional potential, which could be used in varietal selection programs.

Group I is represented by accessions ET01, ET06, ET09, ET11, ET16, ET17, ET18, ET19, ET20, ET25, ET37, ET42, ET47, ET53, ET54, ET62, ET63. They are particularly rich in lipids and energy, low in carbohydrate and cellulose and medium in protein. From a nutritional point of view, this group contains the best accessions that can be valorized by breeding programs and that could find many uses in agri-food and particularly in energetic food formulation programs to fight against undernutrition. Given the high number of accessions in this group, one could think of the presence of duplicates and the need to deepen the knowledge on other physico-chemical and nutritional parameters.

Group II includes accessions ET02, ET07, ET12, ET14, ET15, ET24, ET26, ET28, ET32, ET43, ET46, ET55A, ET55C, ET57, ET67, ET69. From a nutritional point of view, they are less interesting than group I and III accessions, due to their lower lipid and energy contents and high carbohydrate and cellulose contents. These accessions with low nutritional potential could be used as foodstuffs and for the development of dietetic foods.

Group III includes accessions ET03, ET04, ET05, ET08, ET10, ET13, ET21, ET22, ET23, ET27, ET29, ET30, ET31, ET45, ET48, ET49, ET50, ET52, ET55B, ET60, which also have an interesting nutritional potential, although lower than those of group I.

The large variability in nutritional composition observed may be attributable to various environmental factors [35], processes (storage and handling), cultivation and harvesting methods and conditions. Other work on other species has reported that environmental conditions may not be the only cause of variation in the physico-chemical composition of the kernels. Indeed, genetic factors could also influence them [36]. Such hypotheses are confirmed by our results which showed that the variation in the overall composition of the kernels was not a function of the agroecological origin of the accessions, suggesting the influence of these genotypic factors.

\section{Conclusion}

There is large diversity with respect to proximate compositions and potential nutritional values among cashew accessions available in Burkina Faso. Data analysis allowed to classify accessions into three significantly distinct groups. The grouping of accessions independently of their phytogeographical origin suggests the involvement of genetic factors in the variation of the traits of interest. In view of these results, this study is an important step towards identifying the best cultivar to be used for breeding for commercial valorization.

\section{Acknowledgements}

The authors would like to thank the Institut de l'Environnement et de Recherche 
Agricole (Station de Recherche de Farako-Bâ) for providing us with the samples. The authors would like to thank Fonrid for funding this research.

\section{Conflicts of Interest}

The authors collectively declare that there are no conflicts of interest in this article.

\section{Authors' Contributions}

The study protocol was drafted by JNS and LTS-O; the manuscript was written by JNS, LTS-O and MHD. WVT and FB performed the statistical analyses. Scientific supervision of study was provided by LTS-O and MHD.

\section{References}

[1] Trevian, M.T.S., Pfundstein, B., Haubner, R., Würtele, G., Spiegelhalder, B., Bartsch, H. and Owen, R.W. (2005) Caracterisation of Alkyl Phenols in Cashew (Anacardium occidentale L.) Products and Assay of their Antioxydant Capacity. Food and Chemical Toxicology, 44, 188-197.

https://doi.org/10.1016/j.fct.2005.06.012

[2] Asogwa, E.U., Hammed, L.A. and Ndubuaku, T.C.N. (2008) Integrated Production and Protection Practices of Cashew (Anacardium occidentale) in Nigeria. African Journal of Biotechnology, 7, 4868-4873.

[3] Dendena, B. and Corsi, S. (2014) Cashew, From Seed to Market: A Review. Agronomy for Sustainable Development, 34, 753-772. https://doi.org/10.1007/s13593-014-0240-7

[4] Lautié, E., Dornier, M., Filho, M.S. and Reynes, M. (2001) The Products of the Cashew Tree: Characteristics, Upgrading Routes and Markets Fruits. EDP Sciences/ CIRAD, 56, 235-248.

[5] Wardowski, W.F. and Ahrens, M.J. (1990) Cashew Apple and Nut. In: Nagy, S., Shaw, P.E. and Wardowski, W.F., Eds., Fruits of Tropical and Subtropical Origin, Florida Science Source, Lake Alfred, 67-87.

[6] Hiema, F. (2011) Inventory of Cashew Nut Sector Stakeholder Organisations in the Hauts-Bassins and Cascades Regions of Burkina Faso. Ministère de l'agriculture et de l'hydraulique (MAH) et Projet de développement agricole (PDA) de la GIZ, 41.

[7] RONGEAD (2015) The African Cashew Sector in 2015-General Trends and Country Profile. Ouagadougou-RONGEAD \& iCA, 37.

[8] FAOSTAT (Food and Agricultural Organization of the United Nations Statistics Division) (2019) Food and Agriculture Data.

https://www.fao.org/faostat/en/\#data/QCL

[9] MAAH (Museum of African American History)/DGPER (Direction General de la Promotion de l'Economie Rurale) (2018) Cashew Nut Sector in Burkina: Towards the Adoption of a National Strategy for the Development of the Sector. http://lefaso.net/spip.php?article87242

[10] Rico, R., Bulló, M. and Salas-Salvadó, J. (2016) Nutritional Composition of Raw Fresh Cashew (Anacardium occidentale L.) Kernels from Different Origin. Food Science and Nutrition, 4, 329-338. https://doi.org/10.1002/fsn3.294

[11] Ros, E., Tapsell, L.C. and Sabaté, J. (2010) Nuts and Berries for Heart Health. Current Atherosclerosis Reports, 12, 397-406. 
https://doi.org/10.1007/s11883-010-0132-5

[12] Lovejoy, J.C. (2005) The Impact of Nuts on Diabetes and Diabetes Risk. Current Diabetes Reports, 5, 379-384. https://doi.org/10.1007/s11892-005-0097-X

[13] Tsai, C.J., Leitzmann, M.F., Hu, F.B., Willett, W.C. and Giovannucci, E.L. (2004) A Prospective Cohort Study of Nut Consumption and the Risk of Gallstone Disease in Men. American Journal of Epidemiology, 160, 961-968. https://doi.org/10.1093/aje/kwh302

[14] Tsai, C.J., Leitzmann, M.F., Hu, F.B., Willett, W.C. and Giovannucci, E.L. (2004) Frequent Nut Consumption and Decreased Risk of Cholecystectomy in Women. American Journal of Clinical Nutrition, 80, 76-86. https://doi.org/10.1093/ajcn/80.1.76

[15] Jenab, M., Ferrari, P., Slimani, N., Norat, T., Casagrande, C., Overad, K., Olsen, A., Stripp, C., Tjønneland, A., Boutron-Ruault, M.C., Clavel-Chapelon, F., Kesse, E., Nieters, A., Bergmann, M., Boeing, H., Naska, A., Trichopoulou, A., Palli, D., Krogh, V., Celentano, E., Tumino, R., Sacerdote, C., Bueno-de-Mesquita, H.B., Ocké, M.C., Peeters, P.H., Engeset, D., Quirós, J.R., González, C.A., Martínez, C., Chirlaque, M.D., Ardanaz, E., Dorronsoro, M., Wallström, P., Palmqvist, R., Van Guelpen, B., Bingham, S., San Joaquin, M.A., Saracci, R., Kaaks, R. and Riboli E. (2004) Association of Nut and Seed Intake with Colorectal Cancer Risk in the European Prospective Investigation into Cancer and Nutrition. Cancer Epidemiology, Biomarkers \& Prevention, 13, 1595-1603.

[16] Kris-Etherton, P.M., Hu, F.B., Ros, E. and Sabaté, J. (2008) The Role of Tree Nuts and Peanuts in the Prevention of Coronary Heart Disease: Multiple Potential Mechanisms. Journal of Nutrition, 138, 1746S-1751S.

https://doi.org/10.1093/jn/138.9.1746S

[17] Carey, A.N., Poulose, S.M. and Shukitt-Hale, B. (2012) The Beneficial Effects of Tree Nuts on the Aging Brain. Nutrition and Aging, 1, 55-67. https://doi.org/10.3233/NUA-2012-0007

[18] Rivas, A., Romero, A., Mariscal-Arcas, M., Monteagudo, C., Feriche, B., Lorenzo, M.L. and Olea, F. (2013) Mediterranean Diet and Bone Mineral Density in Two Age Groups of Women. International Journal of Food Sciences and Nutrition, 64, 155-161. https://doi.org/10.3109/09637486.2012.718743

[19] Sanhueza, C., Ryan, L. and Foxcroft, D.R. (2013) Diet and the Risk of Unipolar Depression in Adults: Systematic Review of Cohort Studies. Journal of Human Nutrition and Dietetics, 26, 56-70. https://doi.org/10.1111/j.1365-277X.2012.01283.x

[20] Bes-Rastrollo, M., Wedick, N.M., Martinez-Gonzalez, M.A., Li, T.Y., Sampson, L. and Hu, F.B. (2009) Prospective Study of Nut Consumption, Long-Term Weight Change, and Obesity Risk in Women. American Journal of Clinical Nutrition, 89, 1913-1919. https://doi.org/10.3945/ajcn.2008.27276

[21] Soro, D. (2008) Concentration by Tangential Microfiltrtion and Characterization of Cashew Apple Carotenoidquiows Extracts. Master Naval Research. Institute of Hot Regions, Montpellier SupAgro, Montpellier, 67.

[22] Tarpaga, W.V., Bourgou, L., Guira, M. and Rouamba, A. (2020) Agro Morphological Characterization of Cashew Trees (Anacardium occidental L.), in Improvement for the High Yield and High Quality of Raw Nuts in Burkina Faso. International Journal of Biological and Chemical Sciences, 14, 3188-3199.

https://doi.org/10.4314/ijbcs.v14i9.17

[23] French Association of Normalization (AFNOR) (2000) Determination of Water Content, Practical Method. Cereals, Pulses, Derived Products, NF V 03-707. 
[24] International Standardization Organization (ISO) (2007) Determination of Ash Content by Incineration at $550^{\circ} \mathrm{C}$. Cereals, Pulses and Derived Products. ISO 2171.

[25] International Standardization Organization (ISO) (1998) Determination of Fat Content by the Soxhlet Extraction Method. ISO 659.

[26] French Association of Normalization (AFNOR) (1970) General Guidelines for the Determination of Nitrogen with Mineralization According to the Kjedahl Method. Produits Agricoles Alimentaires, NF V 03-050.

[27] Gall, M., Montagne, L., Jaguelin-Peyraud, Y., Pasquier, A. and Gaudre, D. (2002) International Table of Glycemic Index and Glycemic Load Values. American Journal of Clinical Nutrition, 76, 5-56. https://doi.org/10.1093/ajcn/76.1.5

[28] Atwater, W.O., Benedict, F.G., Smith, A.W., Bryant, A.P. and Bryant, M.S. (1899) Experiments on the Metabolism of Matter and Energy in the Human Body. Revised Edition, United States Department of Agriculture, Washington DC.

[29] De Oliveira Sousa, A.G., Fernandes, D.C., Alves, A.M., De Freitas, J.B. and Naves, M.M.V. (2011) Nutritional Quality and Protein Value of Exotic Almonds and Nut from the Brazilian Savanna Ompared to Peanut. Food Research International, 44, 2319-2325. https://doi.org/10.1016/j.foodres.2011.02.013

[30] Trox, J., Vadivel, V., Vetter, W., Stuetz, W., Scherbaum, V. and Gola, U. (2010) Bioactive Compounds in Cashew Nut (Anacardium occidentale L.) Kernels: Effect of Different Shelling Methods. Journal of Agriculture and Food Chemistry, 58, 5341-5346. https://doi.org/10.1021/jf904580k

[31] Aremu, M.O., Olonisakin, A., Bako, D.A. and Madu, P.C. (2006) Compositional Studies and Pysicochemical Characteristics of Cashew Nut (Anarcadium occidentale L.) Flour. Pakistan Journal of Nutrition, 5, 328-333. https://doi.org/10.3923/pjn.2006.328.333

[32] Adouko, O.A.A., Traoré, S., Agbo, E.A. and Kouakou, B. (2016) Functional Properties and in Vitro Digestibility of Cashew Nut Flour. Journal of Food and Nutrition Research, 4, 282-288.

[33] CEE-ONU (Commission économique pour l'Europe des Nations unies) (2012) Section spécialisée de la normalisation des produits secs et séchés. Genève, 18-21 juin 2012, 1-6.

[34] Venkatachalan, M. and Sathe, S.K. (2006) Chemical Composition of Selected Edible Nut Seeds. Journal of Agricultural and Food Chemistry, 54, 4705-4714. https://doi.org/10.1021/jf0606959

[35] Wallis, N.Z., Bagnan, M.A., Akossou, A.Y.J. and Kanlindogbe, C.B. (2016) Morphological Characterization of a Collection of Cashew Fruit from the Municipality of Parakou District (Benin). International Journal of Biological and Chemical Sciences, 10, 2413-2422. https://doi.org/10.4314/ijbcs.v10i6.1

[36] Kumar, S. and Sigh, S. (2014) Variability Assessment of Seed Traits in Jatropha curcas L. for Improvement of Oil Yield. International Journal of Genetics and Molecular Biology, 6, 8-15. https://doi.org/10.5897/IJGMB2013.0079 